\title{
Project International School Cidade Viva: Performance Management by
}

\section{Competence}

\author{
Projeto Escola Internacional Cidade Viva: Gestão de Desempenho por Competência \\ Proyecto Escuela Internacional Cidade Viva: Gestión del Desempeño por Competencias
}

Received: 02/23/2021 | Reviewed: 03/05/2021 | Accept: 05/12/2021 | Published: 05/28/2021

\author{
Francisco das Chagas Bezerra Neto \\ ORCID: https://orcid.org/0000-0001-6232-4383 \\ Universidade Federal de Campina Grande, Brazil \\ E-mail: chagasneto237@gmail.com \\ José Cândido da Silva Nóbrega \\ ORCID: https://orcid.org/0000-0002-0976-3763 \\ Universidade Federal de Campina Grande, Brazil \\ E-mail: jcandidosn@uol.com.br \\ Mônica Barbosa de Sousa Freitas \\ ORCID: https://orcid.org/0000-0001-8073-3359 \\ Universidade Federal de Campina Grande, Brazil \\ E-mail: mbarbosadesousafreitas@ gmail.com \\ Lorena Araújo Rolim Moreira \\ ORCID: https://orcid.org/0000-0002-8738-0549 \\ Universidade Federal de Campina Grande, Brazil \\ E-mail: lorenarolim.cz@gmail.com \\ José Marcolino Neto \\ ORCID: https://orcid.org/0000-0002-4988-8747 \\ Universidade Federal de Campina Grande, Brazil \\ E-mail: joseneto140399@gmail.com \\ Júlia Ingryd Targino de Sousa \\ ORCID: https://orcid.org/0000-0001-8304-3935 \\ Universidade Dr. Leão Sampaio, Brazil \\ E-mail: ingrydjulia@yahoo.com.br
}

\begin{abstract}
The present article aims to analyze the management process of the collaborators of ths Internacional School Cidade Viva, followed by the proposal to implement the Performance Management by Competence model. In this perspective, the present study, through exploratory research, of qualitative nature, deductive method bibliographic data collection, developed in order to point out the tools of this model and its results so that they can provide performance improvement and increase the level of satisfaction of its collaborators. It should be noted that the International School Cidade Viva is a Third Sector institution, therefore, not for profit. Furthermore, it should be noted that their main mission is to promote the integral education of leaders, so that they are able to serve for God and for the neighbor with excellence and to transform the world through Christian ethics. Finally, in view of the proposed objectives, it was sought to outline mechanisms capable of measuring the professional performance of the collaborators. relating it to the ideal competencies for the exercise of its position / function and for the fulfillment of the organizational objectives, in order to identify performance potentials and weaknesses.
\end{abstract}

Keywords: Management; Cidade viva; Performance.

\section{Resumo}

O presente artigo visa analisar o processo de gestão dos colaboradores da Escola Internacional Cidade Viva, seguido da proposta de implantação do modelo de Gestão de Desempenho por Competência. Nesta perspectiva, o presente estudo, através da pesquisa exploratória, de natureza qualitativa, método dedutivo, coleta de dados bibliográfica, desenvolveu-se de modo a apontar as ferramentas deste modelo e seus resultados para que possam proporcionar melhoria de desempenho e aumento do nível de satisfação dos seus colaboradores. Salienta-se que a Escola Internacional Cidade Viva é uma instituição do Terceiro Setor, portanto, sem finalidade lucrativa. Ademais, cabe destacar que sua principal missão é promover a educação integral de líderes, para que sejam capazes de servir a Deus e ao próximo com excelência e de transformar o mundo através da ética cristã. Por fim, diante dos objetivos propostos, buscou-se, traçar mecanismos capazes de mensurar o desempenho profissional dos colaboradores, relacionando-o com as competências ideais para o exercício do seu cargo/função e para o cumprimento dos objetivos organizacionais, de modo a identificar potencialidades e fragilidades de desempenho.

Palavras-chave: Gestão; Cidade viva; Desempenho. 


\begin{abstract}
Resumen
Este artículo tiene como objetivo analizar el proceso de gestión de los empleados de la Escuela Internacional Cidade Viva, seguido de la propuesta para implementar el Modelo de Gestión del Desempeño por Competencias. En esta perspectiva, se desarrolló el presente estudio, a través de una investigación exploratoria, de carácter cualitativo, método deductivo, recolección de datos bibliográficos, con el fin de señalar las herramientas de este modelo y sus resultados para que puedan brindar una mejora del desempeño y aumentar el nivel de satisfacción de sus empleados. Cabe señalar que la Escuela Internacional Cidade Viva es una institución del Tercer Sector, por lo tanto, sin fines de lucro. Además, cabe señalar que su principal misión es promover la educación integral de los líderes, para que sean capaces de servir a Dios y al prójimo con excelencia y transformar el mundo a través de la ética cristiana. Finalmente, a la vista de los objetivos propuestos, se buscó esbozar mecanismos capaces de medir el desempeño profesional de los empleados, relacionándolo con las competencias idóneas para el ejercicio de su cargo / función y para el cumplimiento de los objetivos organizacionales, a fin de identificar el desempeño potenciales y debilidades.
\end{abstract}

Palabras clave: Administración; Cidade viva; Rendimiento.

\title{
1. Introduction
}

The International School Cidade Viva was created in February 2008 by the Evangelical Association First Baptist Church of Bessamar, the Cidade Viva Foundation emerged in a context in which churches, in general, did not have an organizational structure established with the public sector, as well as with the private sector. In this context, it is highlighted that the need to find an appropriate organizational format made Cidade Viva initiate a series of changes and insertions of market tools, adapting them to its reality in the Third Sector.

It is emphasized that even though it is a non-profit organization, there are objectives and results to be achieved and that require management knowledge and skills, in order to consistently and as assertively elaborate its action strategies and development of its activities, in order to the scope of your mission.

The International School Cidade Viva, a subsidiary of the Cidade Viva Foundation, was born in 2010 from a dream linked to the Foundation's Education Hub in partnership with the School Viver e Aprender to provide relevant and differentiated education in Brazil.

The Cidade Viva International School has a differentiated teaching methodology, with full-time nourishment nutrition, where in addition to lectures and awareness events in the classroom, parents or guardians can also choose to include their child (ren) in the nourishment program within the school and receive a complete nutritional follow-up from them. Bilingualism is another differential, because in addition to the two hours of English classes per day, some other subjects are also applied in English, such as physical education classes. It is a Christian confessional school, which seeks in all its interdisciplinary context to strengthen Christian and ethical values among students and staff.

The School is associated with ACSI - International Association of Christian Schools, which establishes partnerships with American and / or English schools to exchange students, as well as encouraging cross-cultural experiences, in addition to the High School Program for students who want the American high school certificate that is the result of a partnership with the Texas Tech University.

The School's pedagogical proposal is based on a socio-constructivist or socio-interactionist, by Lev Vygotsky, the theorist of teaching as a social process, where learning results from the understanding of man as a being formed in contact with society. According to Vygotsky, in the absence of the other, man does not build himself. The interaction that each student establishes with a certain environment is crucial for the so-called personally meaningful experience. The learning experience in question is necessarily actively mediated by an educator. In this proposal, an education of excellence is offered, with updated content, innovative and dynamic didactics, marked by the valorization of interpersonal relationships and the presence of advanced technological resources in the students' daily lives. With the objective of encouraging the integral development of students, the Internacional School Cidade Viva uses revolutionary learning methods and programs, which provide scientifically proven results by increasing the students' integral performance. 
Together with the inauguration of Escola Internacional Cidade Viva in 2010, the Human Resources sector of the entire Cidade Viva System was implemented. Since then, the institution has sought to apply people management tools in a contextual manner in order to develop the potential and promote greater engagement and commitment of its employees in its action strategies.

Finally, it should be noted that the main purpose of the Escola Viva International School is to promote the integral education of leaders, so that they are able to serve God and neighbor with excellence and to transform the world through Christian ethics. In view of the above, this research aims to analyze the management process of the employees of Escola Internacional Cidade Viva, followed by a proposal to implement the Performance Management Model by Competence.

\section{Methodology}

According to the teachings of Marconi and Lakatos (2003, p. 83), "the method is the set of systematic and rational activities that, with greater security and economy, allows reaching the objective - valid and true knowledge -, tracing the path to be followed, detecting errors and assisting the scientist's decisions ".

In this sense, considering that the method has several classifications, this study will be about research based on deductive methodology, which, according to Lakatos and Marconi (1995) starts from existing principles for the elaboration of logical conclusions. Regarding the elaborated article, it will start from the principle of competence, concluding, finally, the efficiency of the personnel policy adopting the management by competences with performance criteria clearly defined in the success of the organization.

In view of the need to understand the organizational field in contemporary times, an exploratory research will be carried out, which aims to provide greater familiarity with the problem. Without the prospect of exhausting the topic, it will be, above all, about the tools of people management.

In addition, qualitative research will be used to prepare the work. In this perspective, "qualitative methods are those in which the researcher's interpretation of opinions about the phenomenon under study are important." (Pereira, Shitsuka, Parreira \& Shitsuka, 2018, p. 67). Thus, it will seek to analyze the topic in question the ideal skills for the exercise of your position / function and for the fulfillment of organizational objectives, in order to identify potentialities and weaknesses in performance.

As for the method of procedure, the monographic method will be attributed, starting from a deep study on the management process of the employees of the International School Cidade Viva, followed by the proposal to implement the Competence Performance Management model. Finally, regarding the procedures used for data collection, the bibliographic technique will be used, seeking to explain the problem in question from the existing theories that address the theme, published in doctrines.

\section{Development}

The concept of competence dates back a few centuries, probably from the time of apprentices of artisans in the Middle Ages. The evolution of this concept, and its use by the human resources area, has been much debated. In an increasingly competitive world, people and organizations need to show better qualifications and results. Therefore, they need to develop their competences (Rezende, 2000). As a result, it is increasingly common for organizations to improve selection methods.

Competence concerns the specificity of the individual, his originality, his life trajectory encompassing his professional experience, his capabilities and potential. She values schooling knowledge, "know-how", experience and "knowing how to be" 
(also called behavioral knowledge) and also social competence (especially in terms of behaviors and attitudes) and also its ability to anticipate problems and not just solve them, showing movement, participation and mobilization (Zarifian, 2001).

Figure 1: Competences as a Source of Value for the Individual and the Organization.

\title{
Individual
}

\author{
Knowing how to act
}

\section{Knowing how to mobilize}
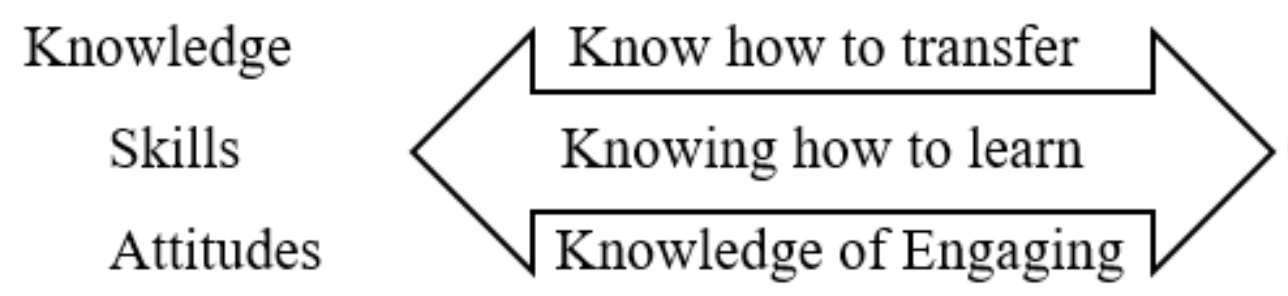

Have a strategic vision

\section{Take responsibilities}
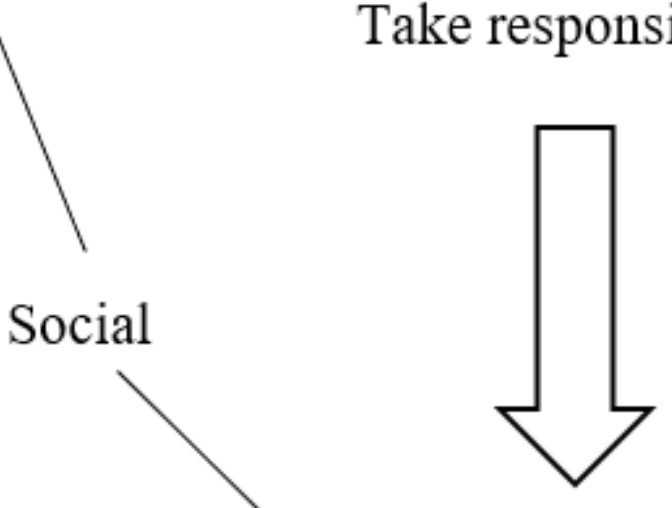

\section{Aggregate value}

Source: Fleury \& Fleury (2001). Adapted.

Aptitude, as Ferreira (1999) indicates a natural or acquired disposition for anything, example: aptitude for Science. Aptitude mainly concerns the physical, physiological, mental or intellectual characteristics or attributes, personality, temperament or character (Resende, 2000).

According to Ferreira (1999, p. 1024), the skill "is the quality of the one who is skilled; ability, dexterity, agility: having the ability to do manual work, cunning". According to Resende (2000) the definition of skill is more related to the way of performing tasks, applying knowledge, acting, thinking. The one who is gifted with skill will certainly find it easy to acquire competence and develop aptitude.

When taking a traditional selection approach, retrospective questions concerning the person's previous life are emphatically used, which is valid, such as: For how many years did you work at a particular company? What are the tasks and responsibilities then? In a competency-based selection, the primary purpose is not to build a candidate's record, but to conduct a survey of their behavior. 
In this sense, inquiries can be related to both the person's past and future. One can then ask how to resolve a particular conflictual issue, what ideas it would have as a solution. This therefore demonstrates the candidate's skills.

In the selection by competencies, the ability to relate is also emphasized, as it is known that this competence is difficult to detect in a selection process if there is not previously a register of the competences of the group with which the person will work. Relationship depends on the skills of the group.

There are basically two lines of thought that were dedicated to the theme: an American one represented by authors such as McClelland, Boyatzis and McLagan and another European represented by (Freitas \& Abreu, 2009).

The North American perspective defends competences as a set of knowledge, skills and attitudes that provide high performance, "a stock of resources that the individual holds" (Fleury \& Fleury, 2001, p. 185).

Fleury and Fleury (2001, p. 193) start from McClelland's studies to define the concept of competence as "a characteristic that underlies a person who is casually related to superior performance in carrying out a task or a given situation".

The defenders of the North American current point to the need to adapt the competences to the demands of the positions in the organizations, that is, the individual, in his competences is equated to a "equipment" that must meet the organizational needs (Freitas \& Abreu, 2009).

The European line originated in the 1970s and reached its peak in the 1990s, arguing that competence implies a confluence of factors (knowledge, skills, attitudes, biography, professional experiences) mobilized in the face of the challenges of situations. In this perspective, the greater the demand, the greater the ability to transform competencies into strengths to overcome challenges, as long as these imply personal and professional growth (Vieira \& Garcia, 2004).

American or European, what matters is that the selection by competences is a very important tool to be applied in any organization with a view to obtain the best result of the selection of personnel.

Within the European line, the focus is no longer simply the function that the individual will perform, but can be thought of in terms of professional career with its spatio-temporal characteristics, representing an evolution in relation to the North American line. Understanding career "as a sequence of positions and work done by the person. Such sequence, articulated in such a way as to reconcile personal development with organizational development " ” (Dutra, 2001, p. 47 apud Freitas \& Abreu, 2009).

The importance given to the selection by competences is due to the fact that it represents a gain factor for the company, since they increase the chances of the company reaching its goals due to the quality of the workforce selected in this mold.

The economic gain can be acquired to the extent of the participation of the collaborators in the elaboration and implementation of the organizational strategies that turn into competitive advantage (Costa, 2003).

There is no doubt that any organization is made up of people and these people must be as competent as possible, so that this translates into the organization's competitiveness in the environment in which it operates.

The competency selection technique arose from the need to develop a method of selecting people that is more compatible with the demands of organizations for flexibility, versatility and adaptability of people, as opposed to suitability for the position, so characteristic of the traditional selection process.

For that, the competency selection method starts from the elaboration of a Competency Profile or Mapping of the position or function, from which one arrives at the competencies considered indispensable for the occupant of the position, within the new organizational requirements. Based on the competences profile (PC), the behavioral interview or target is elaborated, which is the main selection technique alongside games, dynamics and situational tests focused on skills (Freitas \& Abreu, 2009). 
In this way, the demands of globalization require drastic changes in the perception of organizations in relation to the individual values of their collaborators (employees), in order to increase the possibilities of reaching their goals.

In the behavioral interview based on the skills profile, the candidate is sought to get to know the candidate, his professional experiences and his experiences through open, specific questions and always with action verbs in the past, which refer the candidate to an experience already lived. These specific questions will help the selector to ascertain the existence or not of the competences PC (competence profile) in the candidate's behavior (Rabaglio, 2001).

Thus, it can be said, in other terms, that the evaluation of the candidate's previous life is of fundamental importance in the investigation of his competences, as already mentioned.

In the competences interview, these problems are minimized, as the structure of the questions favors the candidate to report what happened and what the consequences were. For example: "Describe to me a situation in which you took responsibility for a task that was not part of your duties"; "Tell me about a negotiation in which you were convinced to change your mind". The main characteristic of this method is to focus on past behaviors, as they serve as predictors of future behavior (Henrique \& Rabaglio, 2007).

Despite the fact that the interview is an important tool for the selection by competences, it cannot be obscured the importance of games as an indispensable tool to complement the interview. On this, Huizinga (1999, p. 33) states:

The game is an activity or voluntary occupation, exercised within certain and certain limits of time and space, according to freely agreed rules, but absolutely mandatory, endowed in itself, accompanied by a feeling of tension and joy and a conscience to be different from everyday life.

Through the games, one can observe the competences of the candidates, such as motivation, leadership, initiative, creativity, innovation, ethics, communication. Each game has a range of possibilities to be explored according to the objective and needs of the selection process. In the games, participants can assume roles or not, but it happens that the participants are always positioned, because in these techniques people reveal facets that they normally try to hide, by inhibition or fear of retaliation (Huizinga, 1999; Gramignia, 1993). Thus, the games lead the candidate to act with a lot of spontaneity, which allows the appraiser to perceive his potentialities with greater clarity.

From this scenario, it can be seen that the selection by competencies is a method that seeks to contemplate concrete experiences that can offer subsidies for the prediction of the candidate's future behavior. It can be used by anyone previously trained, and many authors already tend to the selection to be carried out by managers and not by HR, because they have the knowledge of the desired profile and the position. In this sense, this change favors the approach of the future collaborator with the manager (Henrique, et al., 2007 apud Freitas \& Abreu, 2009).

\section{Final Considerations}

It is perceived, through considerations addressed during the text, that performance management by competence is essential for the success of any organization, since it is through it that companies have the ability to identify talents with the potential to make a difference in this extremely competitive market.

In addition, it is pointed out that one of the key points for the success of the company is the hiring process, which is undoubtedly a great challenge, as it sometimes fails. The lack of adequate criteria and instruments is one of the main reasons for these failures and, consequently, in most cases, it can generate significant financial losses of the most diverse orders. The organizations, aware of the importance of not making mistakes during hiring, have invested financial and human resources for this purpose, as well as seeking to update themselves in the techniques of these competency selection processes. 
Psychological, personality tests and interviews are not enough to choose the right candidate, it is also necessary to find out, if it fits the culture of the organization. Thus, a selection by competencies has to be sufficiently careful in order not to compromise the company's competitiveness in the future.

Furthermore, it should be noted that the selection by competences, one of the indispensable requirements of people management, when adopted by the organization, also, does not mean that all the organization's problems will be solved; continuous improvement, training and qualification programs should be steps to be implemented in the company, with a view to improving the profile of its employees.

In this context, taking into account this need to ensure the achievement of its goals effectively, we believe that investigations like this should be continued. Therefore, as a suggestion for continuing discussions in this sense, analyze, in the light of the survey of Organizational and functional Competences, how the ideal competencies for the exercise of their position / function and for the fulfillment of organizational objectives can be implemented In order to optimize performance in the organizational field, it will contribute to the strengthening and planning of strategies in the organizational scope, as well as to design and formulate new and more effective paths to the organization's success.

\section{References}

Costa, M. A. S. (2003). Strategic administration and management of people by competences: the case of polycarbonates. Master's thesis unpublished. Federal University of Bahia.

Dutra, J. de S. (2001) Competences Management. Ed. Gente.

Fleury, M. T., \& Fleury, A. C. C. (2001). Building the concept of competence. RAC, Special edition.

Freitas, M. de C., \& Abreu, C. V. (2009). Selection by competences. U.F.

Gramignia, M. R. M. (1993). Company games. Makron Books. Editor.

Henrique, M. S., \& Rabaglio, M. O. (2007). Management Gestão por competências: um modelo avançado para o gerenciamento de pessoas. Editora Gente. 2007.

Huizinga, J. (1999). Homo Ludens: the game as an element of culture. Perspectiva.

Lakatos, E. M., \& Marconi, M. A. (1995). Methodology of Scientific Study. Ed. Atlas.

Marconi, M. A.; Lakatos, E. M. (2003). Foundations of Scientific Methodology (5a ed.). Atlas.

Pereira, A. S. et al. (2018). Methodology of Scientific research. UFSM. https://repositorio.ufsm.br/bitstream/handle/1/15824/Lic_Computacao_MetodologiaPesquisa-Cientifica.pdf? sequence $=1$

Rabaglio, M. O. (2001). Selection by competences. Educator.

Resende, E. (2000). The book of competences. Qualimark.

Vieira, M. de C., \& Garcia, C. V. (2004). Selection by competences. U.F.

Zarifian, P. (2001). Competence objective: for a new logic. Atlas. 